\section{Improved Growth of Pecan and Ornamental Pear Trees in Containers with Water-holding Reservoirs}

\author{
Ken Tilt, William D. Goff, David Williams, and Ronald L. Shumack \\ Department of Horticulture and Alabama Agricultural Experiment Station, \\ Auburn University, AL 36849
}

\author{
John W. Olive \\ Ornamental Horticulture Substation of Auburn University, P.O. Box 8276, \\ Mobile, AL 36689-0276
}

Additional index words. Carya illinoinensis, Pyrus calleryana, subirrigation, subsurface irrigation, drainage

\begin{abstract}
Pecan [ Carya illinoinensis (Wangenh.) C. Koch 'Melrose'] and pear (Pyrus calleryana Decne. 'Bradford') trees in the nursery grew more in containers designed to hold water in the lower portion. The water-holding reservoir was obtained either by placing 76-liter containers in a frame holding water to a depth of $6 \mathrm{~cm}$ or by using containers with drainage holes $6 \mathrm{~cm}$ from the bottom. Continuous waterlogging at the bottom of containers resulted in root pruning and root death in the lower portion of the containers, but roots grew well above the constantly wet zone. Fresh weight of plant tops and trunk diameters were greater after two growing seasons in the containers with water reservoirs compared to those grown in similar containers with no water reservoirs. Total root dry weight was unaffected.
\end{abstract}

Despite research on water efficiency for container-grown nursery plants (Fitzpatrick, 1983; Miller et al., 1980), nurseries schedule irrigation for container-grown woody ornamental plants imprecisely and subjectively. Using net evaporation from a class A pan as an irrigation indicator, Martin et al. (1989) found a linear increase in red maple growth from $50 \%$ net evaporation to $400 \%$ net evaporation; however, this system has not been implemented by the nursery industry. Commonly, nursery workers will examine the moisture level in the top 3-4 $\mathrm{cm}$ of medium. If the medium is dry, they irrigate for what they judge to be a sufficient amount of time to thoroughly rewet the medium. This scheduling system can result in fluctuating levels of excessive and deficient moisture in the container medium. Excessive moisture results in inadequate root aeration (Kozlowski, 1985) and can contribute to increased incidence of root-rot diseases such as those caused by Phytophthora (Hagan and Mullen, 1991). Deficient moisture stresses plants. Moisturestress problems develop quickly in a porous medium like pine bark because of its low water-holding capacity. A need exists for nursery workers growing trees in containers to improve water management.

Received for publication 24 Sept. 1993. Accepted for publication 14 Dec. 1993. We appreciate Rigsby Nursery, Ft. Myers, Fla., and Roberts Irrigation, San Marcos, Calif., for donating containers and irrigation supplies. The cost of publishing this paper was defrayed in part by the payment of page charges. Under postal regulations, this paper therefore must be hereby marked advertisement solely to indicate this fact.
One way to improve water management for container trees is to adapt the principles of subirrigation to container production. Subirrigation, as used in crop production (Cooper and Fouss, 1988), is where a water table is maintained at a certain depth beneath the surface of soil by use of an appropriately designed system of underground irrigation and drainage. Above the water table, soil is well drained because the drainage system at a certain depth efficiently removes excessive water quickly; (center) Standard container used as a control. yet sufficient water is readily available to plants because water moves up from the water table by capillary action and roots grow down to the zone of readily available water just above the water table. Properly designed and implemented, such a system has resulted in outstanding growth and yields in many fieldgrown crops. Modifications of the subirrigation concept might be feasible in container production. Our purpose was to examine the effect of a water-holding reservoir in a container on growth of pecan and ornamental pear trees.

\section{Materials and Methods}

A total of 36 container-grown 'Melrose' pecan trees and 36 field-grown 'Bradford' pear trees were ranked according to trunk diameter at $15 \mathrm{~cm}$ above the soil line. Each tree species was assigned, three per block, to each of 12 blocks, with plants of similar trunk diameter assigned to a given block. The experiment was a randomized complete block in a factorial arrangement with two species, three treatments, and 12 single-plant replications. The three trees within a block for each species were randomly assigned to the three treatments. All plants were grown in 76-liter polyethylene containers. Treatments (Fig. 1) were 1) containers with raised drainage holes, also known as Environmentally Friendly Containers (EFC), 2) subirrigation, or 3) standard containers (control). The EFC system was developed and patented by Robert Rigsby of Rigsby Nursery, Ft. Myers, Fla. In this treatment, the drainage holes were located $6 \mathrm{~cm}$ from the container bottom (distance measured from the bottom of the container to the bottom of the the drainage holes). The drainage holes were the same in size $(2.5 \mathrm{~cm}$ in diameter) and number (six) as in the standard containers used for the control. Irrigation was provided by two emitters (Avacado, low flow, spot-spitters;

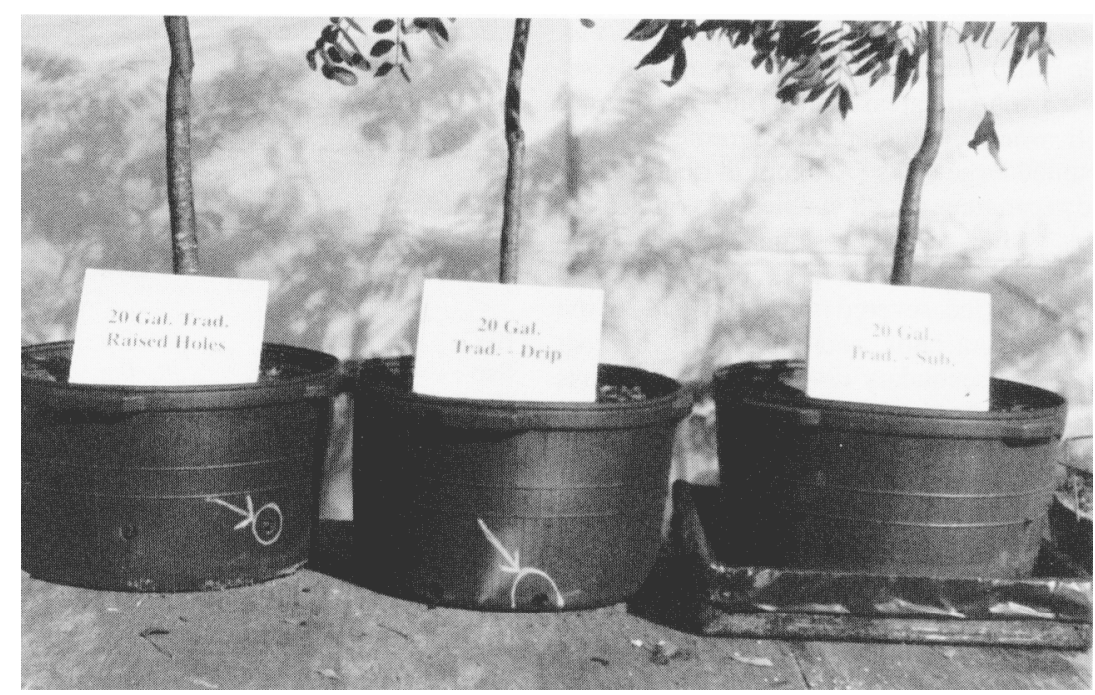

Fig. 1. Water reservoirs at the container base are present in (left) the container with raised holes (Environmentally Friendly Container) (arrows indicate drainage hole location) and in (right) the container with subirrigation, achieved by placing the container in a water-holding, plastic-lined frame. 
Roberts Irrigation Products, San Marcos, Calif.). Each emitter delivered water at 0.45 liters. rein-' in a semicircular pattern, with the pattern of the two emitters together sufficient to wet the entire medium surface. Plants were irrigated for $\approx 20 \mathrm{~min}$ when the upper $3 \mathrm{~cm}$ of the medium appeared dry. Subirrigation was provided by constructing water-holding frames from wood lined with plastic, and placing the containers in the frames. No surface irrigation was provided for these containers, except for rainfall. Frame dimensions were $76 \times 76 \mathrm{~cm}$, and the frame, when full, held 37 liters of water. The frames were filled with water to the full 6-cm depth and were refilled whenever the water level in the frame dropped to $\approx 3 \mathrm{~cm}$. Water entered the container through the drainage holes in the bottom and saturated the medium in the lower part of the container. Thus, the lower $3-6 \mathrm{~cm}$ of the medium in the container was continually saturated for the duration of the experiment. Control trees were grown in traditional 76-liter polyethylene containers with six 2.5 -cm-diameter drainage holes at the bottom of the container, and spotspitter irrigation was used as in the EFC treatment.

Trees were transplanted into the containers for the three treatments in May 1991. All containers held an equal volume, 76 liters, of medium. The medium was 6 milled pine bark :1 sand $(\mathrm{v} / \mathrm{v})$ amended with $\left(\mathrm{kg} \cdot \mathrm{m}^{-3}\right) 8.3$ Osmocote $17 \mathrm{~N}-3.0 P-10.0 \mathrm{~K}$ (12- to 14-month release), 0.9 Micromax micronutrients (Grace/ Sierra Horticultural Products, Milpitas, Calif.), and 3.0 dolomitic limestone. Supplemental Osmocote $17 \mathrm{~N}-3.0 \mathrm{P}-10.0 \mathrm{~K}$ at $500 \mathrm{~g} / \mathrm{pot}$ was topdressed in Apr. 1992.

Plant height and trunk diameter were measured at transplanting on 23 Aug. 1991 and 18 Nov. 1992. Of the 12 trees in each treatment, four were randomly selected for destructive sampling on 18 Nov. 1992; the other eight were retained for field planting in a subsequent experiment. Fresh shoot weights of destructively sampled trees were determined as they were removed from the containers. Visible roots were counted in five randomly selected, $6.5-\mathrm{cm}^{2}$ areas at the bottom of the root ball when containers were removed. We counted large roots $(>10 \mathrm{~mm}$ in diameter) of the pecan trees but all visible roots of the pear trees. After recording counts and observations, the roots from each container were washed, dried, severed from the outside of the original root balls, and categorized by root diameter: secondary $(2-10 \mathrm{~mm})$ and fibrous $(<2 \mathrm{~mm})$ (Fare et al., 1985). There were no primary roots $(>10 \mathrm{~mm})$ extending from the original pretransplanted root balls. The two root categories were weighed. Six media samples were collected for soluble salts and pH measurements on 19 Aug. 1991 for each treatment and species. Samples were collected using a soil probe that extracted medium from the surface to the bottom of the container. Samples were analyzed using a 1 medium :2 water dilution method.

We analyzed data according to the experimental design using analysis of variance and preselected contrasts of interest.

\section{Results and Discussion}

There were no differences for trunk diameter or height of pear trees measured in Aug. 1991. Pecan trees grown in EFC and subirrigation were similar in growth, and both were $\approx 13 \%$ larger in trunk diameter and $6 \%$ taller than the control treatment. In 1992, top growth of plants, whether measured by trunk diameter, height, or fresh weight, was greater in those treatments having water reservoirs at the container bottom (i.e., EFC or subirrigation containers) (Table 1). This result is indicated by the contrast shown in Table 1 for raised holes + subirrigation vs. control. This contrast compares the significance of means associated with the treatments having water reservoirs to the means of the control for both species combined. This contrast is significant for all of the variables measuring top growth, indicating the superiority of the treatments with water reservoirs in promoting top growth. Among individual treatments, EFC was supenor to subirrigation in increasing diameter and top fresh weight in pear, but not in pecan. Raised holes and subirrigation were better than the control for increasing trunk diameter and height in pecan. The absence of a treatment $x$ species interaction suggests a similar response to the treatments in both species.

When we removed plants from the containers and examined root systems, roots were sparse in the poorly aerated layer where water stood at the container bottom. This was especially true with the subirrigation treatment, which had no visible roots at the lower medium surface in either species (Table 2). With $\mathrm{EFC}$, there were visible roots at the lower surface in pear, but not in pecan, indicating an apparently greater tolerance for low $\mathrm{O}_{2}$ in pear

Table 1, Effect of water reservoir treatments on pecan and pear tree growth:

\begin{tabular}{|c|c|c|c|c|}
\hline \multirow[b]{2}{*}{ Treatment } & \multicolumn{2}{|c|}{ Trunk diam } & \multirow{2}{*}{$\begin{array}{l}\text { Plant } \\
\text { ht (m) }\end{array}$} & \multirow{2}{*}{$\begin{array}{c}\text { Fresh wt } \\
\text { of top }(\mathrm{kg})\end{array}$} \\
\hline & Actual (mm) & Increase $(\%)$ & & \\
\hline \multicolumn{5}{|c|}{ Pear } \\
\hline $\mathrm{EFC}^{y}$ & $43 \mathbf{a}$ & $279 \mathrm{a}$ & $2.5 \mathrm{a}$ & $4.3 \mathrm{a}$ \\
\hline Subirrigation (sub) & $39 \mathrm{~b}$ & $245 \mathrm{~b}$ & $2.5 \mathrm{a}$ & $2.8 \mathrm{~b}$ \\
\hline Control & $38 \mathrm{~b}$ & $234 \mathrm{~b}$ & $2.4 \mathrm{a}$ & $2.5 \mathrm{~b}$ \\
\hline \multicolumn{5}{|c|}{ Pecan } \\
\hline $\mathrm{EFC}$ & 39 a & $121 \mathrm{a}$ & $2.5 \mathbf{a}$ & $1.9 \mathrm{a}$ \\
\hline Sub & $40 \mathrm{a}$ & $127 \mathrm{a}$ & $2.5 \mathrm{a}$ & $1,6 \mathrm{ab}$ \\
\hline Control & $34 \mathrm{~b}$ & $95 \mathrm{~b}$ & $2.1 \mathrm{~b}$ & $1.1 \mathrm{~b}$ \\
\hline \multicolumn{5}{|c|}{$P>F$} \\
\hline Significance $^{x}$ & & & & \\
\hline Treatment $(\mathrm{T})$ & 0.0002 & 0.0002 & 0.0002 & 0.0007 \\
\hline Species & 0.0220 & 0.0001 & 0.2388 & 0.0105 \\
\hline $\mathrm{T} \times$ species & 0.0936 & 0.0559 & 0.0768 & 0.0914 \\
\hline $\begin{array}{l}\mathrm{EFC}+\text { sub vs. } \\
\text { control }\end{array}$ & 0.0001 & 0.0001 & 0.0001 & 0.0022 \\
\hline
\end{tabular}

${ }^{4}$ Growth measurements were made on 18 Nov. 1992, following two seasons of growth in the containers. Percent increase is from treatment initiation at repotting in Mar. 1991 until 18 Nov. 1992. Trunk diameter $15 \mathrm{~cm}$ above level of medium.

${ }^{y} \mathrm{EFC}=$ Environmentally Friendly Containers (containers with raised drainage holes).

${ }^{x}$ Within a species and column, mean separation by Duncan's multiple range test, $P \leq 0.05$.

Table 2. Effect of treatments on root development of pecan and pear trees. ${ }^{2}$

\begin{tabular}{|c|c|c|c|c|}
\hline \multirow[b]{3}{*}{ Treatment } & \multirow[b]{3}{*}{ Root count ${ }^{y}$} & \multicolumn{2}{|c|}{ Root dry wt } & \multirow{3}{*}{$\begin{array}{l}\text { Total root } \\
\text { dry wt (kg) }\end{array}$} \\
\hline & & \multicolumn{2}{|c|}{ Root diam } & \\
\hline & & $<2 \mathrm{~mm}$ & $2-10 \mathrm{~mm}$ & \\
\hline \multicolumn{5}{|c|}{ Pear } \\
\hline $\mathrm{EFC}^{\mathrm{x}}$ & $19 \mathrm{~b}$ & $0.16 \mathrm{a}$ & $0.26 \mathrm{a}$ & $0.42 \mathrm{a}$ \\
\hline Subirrigation (sub) & $0 \mathrm{a}$ & $0.11 \mathrm{a}$ & $0.14 \mathrm{a}$ & $0.25 \mathrm{a}$ \\
\hline Control & $23 \mathrm{~b}$ & $0.14 \mathrm{a}$ & $0.19 \mathrm{a}$ & $0.33 \mathrm{a}$ \\
\hline \multicolumn{5}{|c|}{ Pecan } \\
\hline $\mathrm{EFC}$ & $0 \mathrm{a}$ & $0.11 \mathrm{a}$ & $0.15 \mathrm{a}$ & $0.26 \mathrm{a}$ \\
\hline Sub & $0 \mathrm{a}$ & $0.08 \mathrm{a}$ & $0.08 \mathrm{a}$ & $0.16 \mathrm{a}$ \\
\hline Control & $2.3 \mathrm{~b}$ & $0.11 \mathrm{a}$ & $0.10 \mathrm{a}$ & $0.21 \mathrm{a}$ \\
\hline \multicolumn{5}{|c|}{$P>F$} \\
\hline \multicolumn{5}{|l|}{ Significance ${ }^{w}$} \\
\hline Treatment (T) & 0.213 & 0.4416 & 0.2134 & 0.3024 \\
\hline Species & 0.0461 & 0.1585 & 0.0642 & 0.0093 \\
\hline $\mathrm{T} \times$ species & 0.0442 & 0.9607 & 0.8176 & 0.8724 \\
\hline $\begin{array}{l}\mathrm{EFC}+\text { sub vs. } \\
\text { control }\end{array}$ & 0.0387 & 0.8532 & 0.8143 & 0.9121 \\
\hline
\end{tabular}

${ }^{2}$ Root measurements were made on 18 Nov. 1992, following two seasons of growth in the containers.

${ }^{y}$ Root counts represent roots in a $6.5-\mathrm{cm}^{2}$ area that were visible on the lower medium surface when containers were removed on 18 Nov. 1992. For pear, which produced many small roots, the count is for all visible roots of any size. For pecan, which had mostly large roots at this location, the count is for roots with a diameter $>10 \mathrm{~mm}$

${ }^{x} E F C=$ Environmentally Friendly Containers (containers with raised drainage holes).

"Within a species and column, mean separation by Duncan's multiple range test, $P \leq 0.05$. 
and suggesting that this reservoir did not stay saturated as long as the subirrigation treatment. Above the saturated area, root growth appeared substantial and adequate in both species regardless of container type. Neither weight of small fibrous roots $(<2 \mathrm{~mm})$, secondary

Table 3. Effect of treatments on media $\mathrm{pH}$ and soluble salt content. ${ }^{2}$

\begin{tabular}{lrc}
\hline \hline Treatment & $\mathrm{pH}$ & $\begin{array}{r}\text { Conductivity } \\
\left(\mathrm{mS} \cdot \mathrm{cm}^{-1}\right)\end{array}$ \\
\hline & Pear & \\
EFC $^{y}$ & $4.9 \mathrm{a}$ & $0.8 \mathrm{~b}$ \\
Subirrigation (sub) & $4.8 \mathrm{a}$ & $1.1 \mathrm{a}$ \\
Control & $4.8 \mathrm{a}$ & $0.9 \mathrm{~b}$ \\
& Pecan & \\
EFC & $4.6 \mathrm{a}$ & $0.9 \mathrm{a}$ \\
Sub & $4.6 \mathrm{a}$ & $1.5 \mathrm{a}$ \\
Control & $4.7 \mathrm{a}$ & $0.9 \mathrm{~b}$ \\
& $P>F$ & \\
Significance & & \\
Treatment (T) & 0.4840 & 0.0008 \\
Species & 0.0407 & 0.4026 \\
T $\times$ species & 0.5347 & 0.2919 \\
EFC + sub vs. & & \\
$\quad$ control & 0.3537 & 0.0738 \\
\hline
\end{tabular}

${ }^{z}$ Measurements were made on 18 Aug. 1992, following two seasons of growth in the containers.

${ }^{y} \mathrm{EFC}=$ Environmentally Friendly Containers (containers with raised drainage holes). roots $(2-1 \mathrm{O} \mathrm{mm})$, or total root weight differed among treatments in either species. Thus, increased root growth in the upper portion of the container in the treatments with water reservoirs apparently compensated for the sparse or absent root growth in the lower portion of these containers.

Treatments had no effect on medium $\mathrm{pH}$, but they did affect soluble salt content as reflected by the electrical conductivity (Table 3 ). In both species, conductivity was highest in the subirrigation treatment; however, all soluble salt levels were acceptable. The subirrigation treatment likely accumulated all leached salts from the containers.

Our data show several advantages from maintaining a water reservoir for containergrown plants. They may temper moisture fluctuations and reduce drought stress. Improved growth may be related to continuous access of roots above the continuously wetted zone to the water contained in the reservoirs. Also, the reservoirs conserve water by reducing runoff of excess water commonly applied in conventional systems. They also could reduce leachate-related contamination of runoff water from nurseries. Another advantage is the root-pruning effect at the container base. Because roots stopped growing when they encountered the wetted zone, curling and kinking of large roots, as often occurs in standard containers in many trees, and rooting-out into container beds was reduced. Even if there was no increased growth advantage, these other advantages still make containers with water reservoirs worthy of consideration. We believe further study with a broader range of plants is warranted.

\section{Literature Cited}

Cooper, J.R. and J.L. Fouss. 1988. Rainfall probabilityforecastsused to manage a subdrainagesubirrigation system for water table control. Agr. Water Mgt. 15:47-59.

Fare, D. C., C.H. Gilliam, and H.G, Ponder. 1985. Root distribution of two field-grown Ilex. HortScience20:1129-1130.

Fitzpatrick, G. 1983, Relative water demand in container-grown ornamental plants. HortScience 18:760-762.

Hagan, A. and J. Mullen, 1991. Phytophthora root rotof woody ornamentals. Alabama Coop. Ext. Serv. Circ. ANR-571.

Kozlowski, T.T. 1985. Soil aeration, flooding, and treegrowth.J. Arboriculture 11(3):85-96.

Martin,C.A., H.G. Ponder, and C.H. Gilliam. 1989. Effectsofirrigationrate and media on growth of Acer rubrum L. in large containers. J. Environ, Hort. 7(1):38-40.

Miller, M. N., D.L. Gunter, B.E. Melton, C.R. Johnson, and J.T. Midcap. 1980. Selecting economically optimal levels of fertilization and irrigation for container production of woody ornamental. J. Amer. Soc. Hort. Sci. 105:766768. 